\title{
Public Policy Making in the Coastal Zone of the Venice Lagoon: Is There a Good Balance between Economic Development, the Social Dimension and Environmental Protection?
}

\author{
Maria Sabrina De Gobbi* \\ University of London, London, UK \\ Email: sabrina.degobbi@gmail.com
}

Received July 22 ${ }^{\text {nd }}$, 2013; revised August 26 ${ }^{\text {th }}$, 2013; accepted September $15^{\text {th }}, 2013$

\begin{abstract}
Copyright ( 2013 Maria Sabrina De Gobbi. This is an open access article distributed under the Creative Commons Attribution License, which permits unrestricted use, distribution, and reproduction in any medium, provided the original work is properly cited.
\end{abstract}

\begin{abstract}
This paper shows how much citizens' views are taken into account in local policy decision-making concerning the management of the coastal area of the Venice Lagoon. Through the application of a somewhat innovative version of the contingent valuation method (CVM), it is possible to understand how to set a good balance among economic development, the social dimension and environmental protection in a coastal zone. The methodology allows for a clear assessment of the economic value of non-use values. In 2010, an online survey was conducted in the Venice area to find out how local much citizens value two protected areas in the Venice Lagoon. Four hypotheses were tested to find out whether the age of respondents, the municipality where they live, their income level, and the visited and protected sites are factors determining a different willingness to pay for environmental protection. The economic, social and environmental situation of the coastal zone of the Venice Lagoon in 2010 was then compared to that of 2012 to try to draw conclusions on the level of sustainability of the management of the Venice coastal area. The comparison indicates that there have been some improvements in citizens' participation in decision-making processes through political events.
\end{abstract}

Keywords: CVM; Lagoon; Sustainable Development; Tourism

\section{Introduction}

\section{Objective}

The objective of this paper is to show how, through the application of a somewhat innovative version of the contingent valuation method (CVM), it is possible to understand how to set a good balance among economic development, the social dimension and environmental protection in a coastal zone. The methodology is innovative that it allows for a clear assessment of the economic value of both use and non-use environmental values. The case of the Venice Lagoon is presented, not because it constitutes good practice, but rather shows a concrete application of the method and how it can be used to try to achieve sustainable development in the management of a coastal area, including citizens' participation in local policy decision-making.

The research question that this paper addresses is:

- How much do local citizens value protected areas in the Venice Lagoon?

An online survey was conducted in the Venice area to answer this question. Four hypotheses were tested to find out whether

\footnotetext{
*The author is a research economist at the International Labour Organization. However, this paper is based on research work which the author conducted when she was studying at the University of London. Neither the ILO's nor the University of London's affiliations are to be used. In particular, the views expressed in this article are the sole responsibility of the author and do not necessarily reflect those of the ILO.
}

the age of respondents, the municipality where they live, their income level, and having visited the protected sites are factors determining a different willingness to pay for environmental protection.

The following sections of this chapter will provide some background information on the social and economic development of the Venice area, on the Venice Lagoon, and on protected areas. The methodology used and the results will be described in specific chapters. An additional chapter will focus on findings and compare them to the present situation to show to what extent the Venice Lagoon is being managed in a sustainable way. Some general remarks will conclude the paper.

\section{Economic and Social Development}

The Venice Lagoon is located within the territory of the Veneto region. Veneto is one of the richest regions in Italy and economically one of the fastest growing in Europe (Regione del Veneto, 2009e). In 2006, Veneto was the region in the country with the highest level of openness to trade and international exchanges with a high volume of exports (Regione del Veneto, 2008a). In 2010, Veneto was the second region in Italy with the highest volume of exports (Regione del Veneto, 2011). The development of infrastructure plays a pivotal role in favouring trade flows. The Port of Venice has historically been and continues to be a major agent for trade development in the region.

The economy of the Venice area traditionally and largely 
depends on industry, including the chemical, metal and oil sectors, as well as the production of ships and aircrafts (Ibid). These sectors have been and are being negatively affected by the unfavourable international economic situation of the past few years which is causing widespread unemployment. The only economic sector which has been consistently recording a positive trend is tourism (Autorità Portuale di Venezia, 2011).

The most recent data (2009) indicate that Veneto has been the first Italian region in terms of tourism flows for several years (Regione del Veneto, 2011). The province of Venice hosts the largest share of tourists, comprising 56 per cent of the region's tourists in 2009. In the same year, 54 per cent of newly recruited employees in the Venice area found a job in this sector (Ibid). Over two million passengers visited Venice in 2010 with a 9.1 per cent increase compared to 2009. If only cruise passengers are considered, that increase reaches 12.5 per cent (Autorità Portuale di Venezia, 2011). The good economic performance of tourism has made regional and local authorities prioritize investments aimed at further boosting the development of this sector ${ }^{1}$.

\section{The Venice Lagoon}

When Venice and its surrounding territories were an independent republic up until the XVIII century, the lagoon was considered as an invaluable common good because it secured independence, protection from external attacks and prosperity. Even well-justified private interests to use and exploit the lagoon were strongly opposed in the name of public interests (Comune di Venezia, 2009).

The Venice Lagoon comprises very heterogeneous, closely interconnected and interacting habitats. It consists of open waterbodies, river mouths, shallow waters, water-bodies of lower salinity, and canals. A total of 79 species of fish and 300 species of microalgae have been identified (Solidoro et al., 2010). Eel-grass zostera and Ruppia cover the bottoms of the waterbodies. Sea-lettuce Ulva and Enteromorpha, and cord-grass Spartina are common in these areas (BirdLife International, 2009).

Flat islands which are often covered by water are typical and fundamental for birds of many species, several of which are endemic. These areas host some 100,000 wintering water birds such as Fulica Atra and Calidris Alpina. Breeding herons and post-breeding terns, such as Sterna albifrons and Chlidoniasniger, record their largest populations in Europe in the Venice Lagoon (Ambito Territoriale di Caccia Lagunare Venezia, 2009; BirdLife International, 2009).

A priority plant species in need of protection according to the EU Habitat Directive, Salicornia veneta, can be found in this area (Regione del Veneto, 2009c). Two globally threatened species are also present: pygmy cormorant or Phalacrocorax pygmaeus, and redshank or Tringa totanus (Smart \& Vinals, 2004).

Morphological changes due to sediment variations and sea level rise, natural and anthropogenic subsidence, land reclamation, and dredging of channels for industrial development determine varying physical, chemical, biogeochemical, and biological conditions which favour or hinder the presence of dif-

\footnotetext{
${ }^{1}$ For an overview of the negative impacts of infrastructure development, tourism and cruise ships on coastal zones, see Davenport, J., Davenport, J. L., 2006. The impact of tourism and personal leisure transport on coastal environments: A review. Estuarine, Coastal and Shelf Science, 67, 280-292.
}

ferent species in the Venice Lagoon (Solidoro et al., 2010). The area of the Venice Lagoon is almost entirely covered by a management plan and benefits from conservation measures (Regione del Veneto, 2009f, g). It is nonetheless to be noted that, although some management plans for sites which are protected under EU legislation have been prepared, they cannot be implemented due to the poor organizational capacity of designated authorities.

The main threats to the lagoon ecosystems are fish farming, aquaculture, hunting, tourism by boat, coastal erosion, wastes from agriculture, and industrial activities. A major industrial area comprising chemical and oil activities was established along the coastal zone in Porto Marghera causing significant negative environmental impacts. New deep navigation channels were dredged and part of the lagoon was modified for the discharge of effluent water (casse di colmata) which caused heavy pollution (Solidoro et al., 2010). In the 1960s, a reclamation process began and the area was spontaneously colonised by local species, including trees like poplars (Ambito Territoriale di Caccia Lagunare Venezia, 2009; BirdLife International, 2009; Regione del Veneto, 2009c).

In its Triennial Plan (Piano Triennale) 2008-2011, the Venice Port Authority announced a considerable expansion of the existing Port of Venice in order to enhance economic development and meet increasing national and international trade needs. To meet the increasing demand for cruise ships services, in 2010 the Venice Port Authority envisaged the creation of a side tourism harbour for cruise ships. One possibility was to establish such a harbour on the coastal area of the Mira Municipality (Autorità Portuale di Venezia, 2008a, b).

The administration of the Mira municipality maintained a rather ambiguous position with respect to this project (Regione del Veneto, 2008d; Autorità Portuale di Venezia, 2008a, b, c; Comune di Mira, 2010). To estimate how much local inhabitants value their territory, a survey was conducted using a sample of 4307 citizens living in the Venice area. Obviously, if local citizens do not much value their surrounding territory, the idea of creating a new harbour to enhance economic activity in the area cannot be considered as politically wrong, although what makes political sense often results in environmental mismanagement and failure (Amizaga \& Santamaría, 2000; Turner et al., 2000).

\section{Protected Areas}

Following the adoption of EU directives 1979/409/EC and 1992/43/EC, two types of protected areas have been established. Based on the EC Habitat Directive, Veneto has set up 102 Sites of Community Importance (SCIs) which contribute to the formation of the Natura 2000 ecological network. For the implementation of the Wild Birds Directive, 67 Special Protection Areas (SPAs) have been established along the migration paths of wild birds. These two types of protected areas often overlap, so that overall there are 128 protected sites for a total surface of 414.628 ha (Regione del Veneto, 2009b, d).

The presently protected areas are the result of institutional tensions and conflicts which have pushed the Veneto regional authorities to expand the size of those areas. The most recent measure in this regard is an increase of SCIs and SPAs in the Venice Lagoon following a 2003 decision of the EU Court of Justice against Italy for the insufficient number and size of protected areas (Ambito Territoriale di Caccia Lagunare 
Venezia, 2009; Regione del Veneto, 2009h).

The wetland Ramsar Convention is another international legal instrument which is supposed to guide actions with an impact on the environment in the areas under its protection. Several attempts have been made by local authorities and the international community to extend the coverage of the currently existing Ramsar site to the entire Venice Lagoon, but presently only the natural reserve Valle Averto with a surface of 500 ha is a Ramsar site (Ramsar Convention, 2004; Smart \& Viñals, 2004).

An additional element which is to be considered for the management of the Venice Lagoon is the fact that the "City of Venice and its Lagoon” are a UNESCO World Heritage Site. This means that the cultural values of wetlands, including the participation of local communities for the conservation of their cultural heritage, are to be taken into account for the effective management of the area (Suman et al., 2005).

Interestingly, the proposed area where the new port (an extension of the Venice harbour) should have been created overlaps with two protected areas: a Habitat Directive priority site and a Wild Bird Directive Special Protection Area (Regione del Veneto, 2008b, c). Presently, cruise ships have direct access to the city of Venice, creating damage to old historical monuments with high and frequent waves causing the erosion of buildings (Smart \& Viñals, 2004; Italia Nostra, 2010). This is why their access to the city should be forbidden. But should protected areas be negatively affected instead?

\section{Methodology}

The research question which the present paper addresses is:

- How much do local citizens value protected areas in the Venice Lagoon?

An online survey is the main method which has been used to collect data to answer the research question above. In particular, the contingent valuation method (CVM) was applied to find out how much local citizens in the Venice province value their surrounding environment. This method is an "expressed preference technique" in that surveyed individuals are asked to express a specific level of preference for a given environmental change. In this case, it was possible to estimate willingness to pay (WTP) of local citizens for a concrete proposed environmental change consisting of the improvement of two protected areas as opposed to the likely creation of a new cruise ship harbour on the same site of the Venice Lagoon. Local expert opinions and the views of technicians working in local administrations at different levels helped to deepen and further develop the technical arguments.

The technique used and described in Birol et al. (2006) to value environmental changes in a Greek wetland served as a guiding example. As in the Greek case, the question that surveyed individuals were asked is "How much would you be willing to pay for ...?” The amount expressed indicates the annual tax level they would be willing to invest to maintain the protected areas as they are and strengthen the management plan through the recruitment of experts to monitor flora and fauna and to improve ecological, educational and recreational services.

Unlike Birol et al. (2006) who used an open-ended question, a discrete choice format was adopted, as recommended by King and Mazzotta (2000). A total of 10 values were proposed, from 0 to 150 Euros, among which respondents were asked to choose one.

The CVM has been chosen because it allows non-use values to be measured in economic terms. Non-use values are becoming increasingly important on a path towards sustainable development.

Non-use values are difficult to measure (Pagiola et al., 2004; DEFRA, 2007). To facilitate measurement, eight options corresponding to direct and indirect use values, as well as non-use values were listed in the questionnaire. An additional option could be specified by respondents to add any further value. Respondents were asked to choose up to three options to justify their payment or indicate their priority values. It was thus possible to attach a precise monetary value to each of the eight values. This technique was inspired by-but not entirely based on - the approach used by Barbier et al. (1997), Allen et al. (2003), Brander et al. (2006), and Burton and Tiner (2009).

One last option, the tenth, indicated a lack of interest in the protection of the sites.

The issue of double counting of values (DEFRA, 2007) through the options in the list mentioned above was addressed through a very simple description of each value. Those values which may be difficult to explain, and for respondents to understand, such as "option values" as described in Birol et al. (2006), were intentionally excluded. By so doing, what individuals are willing to pay should match specific environmental values described in the proposed options.

A focus group discussion was conducted before launching the survey. The focus group comprised 10 individuals from the Venice area aged between 18 to 65, with different technical backgrounds (e.g. environmental engineer, architect, ecologist, etc.), and working in institutions such as local and regional public authorities, private firms, NGOs and universities. No major issue was raised and only minor changes were made to the questionnaire. It became clear that the adoption of a discrete choice format does not solve the problem of 'protest bids' from those who do not accept any trade-off between money and the environment.

The sampling frame is the population of the Venice province who are of age and have access to online services. An informal sampling method or a non-probability sampling approach has been adopted. As a matter of fact, only those individuals living in the Venice province who are of age, have access to a computer and have voluntarily registered in an online database run by the private firm which agreed to process the questionnaire for the present report are part of the sample. Registration makes it possible to obtain specific personal data necessary to properly address the research question. In Italy, privacy legislation is very strict and requires a formal agreement for the use of personal data. This approach has been chosen for convenience and ethical reasons. Findings can be generalised to the entire population of the Venice province in a limited way because of the informal method used, and since the response rate is low.

Some 4307 individuals were registered at the moment when the survey was launched. They all received invitations to fill in the questionnaire via E-mail. Data on sex, age, occupation and municipality/district of individuals were already available in the database. The questionnaire consisted of five questions and included two photos of birds which served as flagship species for the protected areas under discussion. Three maps were also added to help respondents understand the situations described.

Four hypotheses were tested to find out whether the age of respondents, the municipality where they live, their income 
level, and having visited the protected sites are factors determining a different willingness to pay for environmental protection $^{2}$.

A major weakness of the method applied is that the survey has not been conducted based on random sampling. However, findings can still be considered as useful to shed some light on local issues which deserve more attention and research. Moreover, the method can certainly be applied in other, similar situations where larger samples are available and more reliable results could be obtained.

Another limitation is the fact that the sample used includes more men than women, which is reflected in the gender breakdown of responses.

As already mentioned, the CVM offers the advantage of measuring non-use values in economic terms, but also has several weaknesses. One is that it may provide some biased responses (King \& Mazzotta, 2000) as can be observed in the presentation of results in the following chapter.

\section{Results}

The total number of responses received is 153 , but only 127 were complete and could be used. Although low, this number was deemed sufficient considering that Birol et al. (2006) conducted their CVM analysis on 122 responses and Hanley and Craig (1991) on 129.

Men comprise 74.8 per cent of the total, and average age is 35.2. Average WTP (mean) is 26.81 Euros. Twenty five respondents opted for 0 and two did not care about the protected areas.

Table 1 shows the total economic value that respondents on average are willing to pay with a breakdown by environmental value.

A distinction is made between use values, which represent the value individuals assign to environmental resources by using them, and non-use values, which correspond to the value derived from environmental goods even without using them.

Table 1.

Respondent willingness to pay, by environmental value.

\begin{tabular}{|c|c|c|c|c|}
\hline $\begin{array}{c}\text { Environmental } \\
\text { value as a } \\
\text { component of } \\
\text { TEV }\end{array}$ & $\begin{array}{l}\text { Environmental } \\
\text { value }\end{array}$ & $\begin{array}{l}\text { Economic } \\
\text { value (\%) }\end{array}$ & $\begin{array}{l}\text { Value in } \\
\text { Euros }\end{array}$ & $\begin{array}{c}\text { Economic value } \\
\text { of use and } \\
\text { non-use values } \\
\text { in Euros }\end{array}$ \\
\hline Direct use & $\begin{array}{l}\text { Recreation/ } \\
\text { tourism }\end{array}$ & 14.5 & 3.89 & \\
\hline Direct use & $\begin{array}{l}\text { Fishing and } \\
\text { hunting }\end{array}$ & 3.2 & 0.86 & \\
\hline Indirect use & $\begin{array}{c}\text { Ecological } \\
\text { services }\end{array}$ & 10.1 & 2.70 & \\
\hline Indirect use & $\begin{array}{l}\text { Climate change } \\
\text { mitigation }\end{array}$ & 6.6 & 1.77 & $\begin{array}{l}9.22 \text { (use } \\
\text { values) }\end{array}$ \\
\hline Bequest value & $\begin{array}{c}\text { For future } \\
\text { generations to } \\
\text { visit }\end{array}$ & 18.3 & 4,91 & \\
\hline Altruistic value & $\begin{array}{c}\text { For other } \\
\text { people to visit }\end{array}$ & 13.3 & 3.56 & \\
\hline Existence value & $\begin{array}{l}\text { Cultural } \\
\text { heritage }\end{array}$ & 17 & 4.56 & \\
\hline $\begin{array}{c}\text { Existence/ } \\
\text { intrinsic value }\end{array}$ & $\begin{array}{l}\text { Biodiversity } \\
\text { conservation }\end{array}$ & 17 & 4.56 & $\begin{array}{c}17.59 \text { (non-use } \\
\text { values) }\end{array}$ \\
\hline Total & & 100 & 26.81 & 26.81 \\
\hline
\end{tabular}

Note: Classification of use and non-use values adapted from Birol et al. (2006). Source: Survey data.

${ }^{2}$ The two-samples Mann-Whitney U-test was used.
Use values can then be divided into direct use which is the consumptive use of an environmental resource, and indirect use which includes indirect benefits derived from an environmental good such as ecological services. Non-use values include existence values which aim to preserve an environmental resource not to be used in the present or future, bequest values for future generations to use, and altruistic values for other people in the same generation to use (adapted from Birol et al., 2006). Figure 1 shows the total economic value of environmental use and non-use values based on survey data.

Three critical issues which emerged from the application of the CVM include:

- Strategic bias: A 22-year-old student offered 150 Euros. The student may know she would not have to pay the tax, but tried to influence the outcome and chose the option with the maximum tax level.

- Protest bias: A respondent offered 0 Euros and added that she already has too many taxes to pay, and those should already include government actions for environmental protection. Her protest is not against environmental protection as such.

- Non-response bias: Those who answered the questionnaire are likely to have different values than those who did not respond. This problem was partly addressed through the payment of a symbolic amount of money (contributing to a telephone recharge) for completing the questionnaire ${ }^{3}$.

Of all respondents, 75.6 per cent had visited the sites, and 67.7 per cent had never heard of the Mira harbour project before.

In order to test the hypotheses, some considerations on the distribution of WTP as a variable are necessary. As for many economic variables, the distribution of "willingness to pay" values is positively skewed, with the median (10) and the mode (10) being less than the mean (26.81). A non-parametric test was therefore used. Medians were compared instead of means as would be the case if parametric statistics had been used.

The result of the test of the first hypothesis on whether there is a difference in how citizens under or equal to 35 years of age value environmental protection compared to citizens who are over 35 is clear: there is no difference. Age seems to have no impact on how individuals value environmental protection.

Those who live close to the lagoon value the two sites more than those who live in internal areas and citizens with lowincome occupations value environmental protection less compared to citizens with higher-income occupations. Moreover, having visited the sites makes citizens value environmental protection more.

In skewed distributions, where there may be extreme values, the median is preferred to the mean (Howell \& Kent, 2008). The data considered until now should therefore be revisited and additional results presented.

Concerning willingness to pay in general, the median is 10 Euros, which is considerably less than the mean 26.81 Euros. For the groups in the three hypotheses where a difference has emerged:

- respondents from municipalities with access to the lagoon are willing to pay 20 Euros compared to individuals from internal municipalities who offer 10 Euros;

- citizens with higher-income occupations are willing to pay 20 Euros as opposed to those with low-income occupations

\footnotetext{
${ }^{3}$ See www.eurosms.org/.
} 


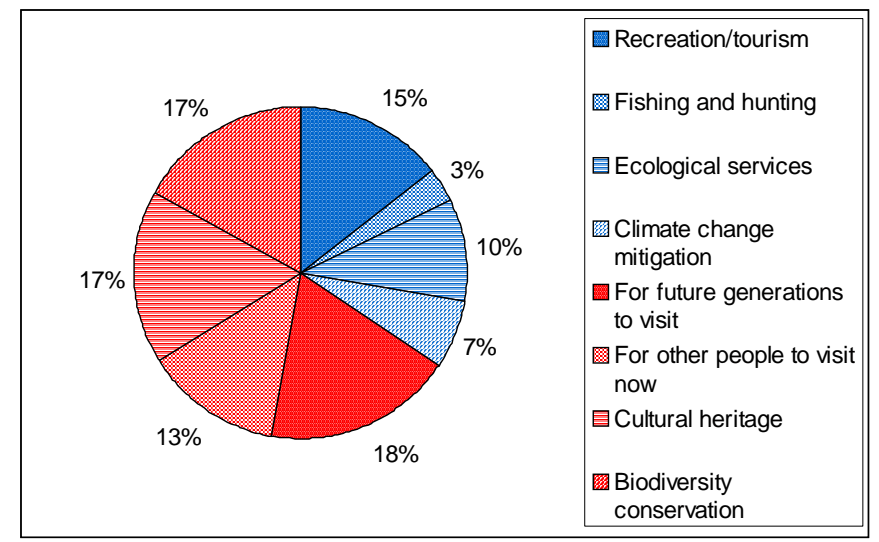

Figure 1.

Total economic value with distinction between use (blue) and non use (red) values (\%).Source: Survey data.

who are willing to offer 10 Euros;

- respondents who have visited the sites are willing to pay 20 Euros, whereas those who have not offer 10 Euros.

It may be appropriate to apply the value in Euros of environmental values presented in Table 1 to an amount reflecting medians rather than the total mean (26.81 Euros). An amount of 10 - 15 Euros could be used instead.

\section{Discussion}

\section{How Much Do Local Citizens Value Protected Areas in the Venice Lagoon?}

The research question addressed in the present paper is clearly answered. On average, local citizens are willing to pay 26.81 Euros through an annual tax to safeguard and improve the protected areas of the Venice Lagoon. This result is in line with findings presented in Birol et al. (2006) where Greek citizens were willing to pay 22.3 Euros through a one-off tax for a proposed change to keep/improve a wetland and 34.9 Euros for a different modification concerning the same site.

What similar applications of CVM (Bateman et al., 1995; Birol et al., 2006; Hanley \& Craig, 1991) do not consider is that, since the distribution of the WTP variable is skewed, medians should be preferred to means (Howell \& Kent, 2008). The amount obtained for citizens in the Venice area is much lower and is equal to only 10 Euros. However, this is possibly a more reliable figure for policy planning.

The finding that citizens living closer to the protected area are willing to pay more is in line with the results obtained by Bateman et al. (1995), and the higher WTP of those who have visited the site as opposed to non-visitors corresponds to findings presented in Hanley and Craig (1991). The fact that higher income determines a higher WTP for environmental protection is clearly shown in Brander et al. (2006), where an increase of 10 per cent of per capita income corresponds to a 12 per cent increase in the value attributed to wetland. The issue of higher income resulting in higher WTP is often discussed in the international literature, particularly with regard to citizens in poor countries as compared to populations in advanced economies (Allen et al., 2003).

The limited number of responses and the informal sampling method used do not make aggregate estimates of environmental valuation for the entire Venice province desirable, although this has been done in similar cases (Bateman et al., 1995; Hanley \& Craig, 1991). In the present paper, it is preferred to state that respondents are willing to pay 10 - 15 Euros per capita to keep/improve the two protected areas. Further research based on a larger and possibly random sample is needed to confirm this finding. It is however clear that local citizens do care about the protection of their surrounding environment and are not supportive of the idea of creating a new harbour where the two protected areas are located.

\section{Findings from Preferred Use and Non-Use Values}

In their CVM study, Birol et al. (2006) do not make any attempt to interview visitors of the site, as their objective was to measure non-use values only. Commenting on the survey by Bateman et al. (1995), Barbier et al. (1997) regret that no clear distinction between non-users and past users was made. In their view, this aspect may hinder a correct valuation of non-use WTP.

The survey presented in the present paper tries to overcome some of the limits of measuring non-use values. A clear distinction is made between visitors and non-visitors, and a precise economic value is attributed to different specific use and nonuse values.

A striking result is that the first three preferred environmental values are non-use values. These are respectively "for future generations to visit the sites" (18.3 per cent), and "biodiversity conservation" and "cultural heritage," both reaching a share of 17 per cent of total preferences. As shown in Figure 1, the total proportion of preferences for non-use values comprises 65.6 per cent of total economic values. Irrespective of age, local citizens clearly value non-use values more than use ones.

The first preferred use value comes fourth in order of preferences expressed. It is a direct use value (for tourism/recreation) which represents 14.5 per cent total expressed preferences.

Considering that those who have visited the sites comprise a large majority of respondents (75.6 per cent) and are willing to pay more than non-users, the fact that non-use values are preferred to use ones is quite surprising, given that it is use values and not non-use ones which are linked to the actual use and/or consumption of the environmental asset at stake. This finding is also counter-intuitive in light of the approach adopted by Birol 
et al. (2006) and comments by Barbier et al. (1997) reported above.

These findings indicate that local citizens value sustainable development much more than their policy makers. Taking as reference the definition of sustainable development provided in the 1987 UN Brundtland report, sustainable development meets the needs of both present and future generations (Sands, 2003). Local citizens would rather direct public investment towards the safeguard of the environment for future generations, biodiversity conservation, the protection of their cultural heritage, and for other people to visit the sites (65.6 per cent of preferences) than towards the creation of infrastructure for economic development.

It is to be noted that one aspect of the social component of sustainable development is included both in the proposed environmental improvement of the two protected areas and in the creation of a new harbour, with the generation of employment in both cases. This means that, with equal consideration for employment, environmental protection is preferred to strictly economic development.

As described in section 1.2, infrastructure development and tourism are two major threats to biodiversity. Rethinking development in more sustainable terms ought to be a priority for local and regional policy makers. Alternative economic activities with an equal employment effect, but more compatible with environmental protection are to be sought. The implementation of management plans for protected areas offers a viable opportunity in this regard.

Useful lessons can be learnt considering the recent experience of the Republic of Korea and its "Green New Deal” (Barbier, 2010; Cheong Wa Dae, 2009; Korea.net News, 2009a, b), as well as from the Millennium Ecosystem Assessment (2005). In the Republic of Korea, in reaction to the devastating social effects of the recent economic crisis, jobs have been created through projects for the improvement of rivers in the country. The Millennium Ecosystem Assessment presents ideas for jobs in environmental improvements such as planting trees against coastal erosion. Blanch (2008) offers other examples of economic activities and jobs which are compatible with sustainable development in Northern Australia. These examples include culture-based tourism and payments for ecosystem services such as carbon stewardship and nature conservation.

\section{Findings on Awareness of Policy Decision-Making}

The majority of respondents (67.7 per cent) were not aware of the project to build a cruise ship harbour within the territory of the Mira municipality. This finding indicates that policy-makers do not seek to adopt a participatory approach, and if they do, they are rather unsuccessful.

Sadly, Borrelli et al. (2007) reveal that in Italy a law called "Law Objective" has been adopted to allow top-down approaches ignoring citizens' participation in decisions concerning the approval of public works projects pursuing the final objective of national interest. This law supersedes environmental impact assessment legislation. Should the project of building a cruise ship harbour in the Mira municipality be implemented, such law could well be applied.

The case of Torcello, an island in the Venice Lagoon, can be mentioned as evidence of what may happen when decisions are made using a top-down approach with no public participation. Public opposition to morphological and environmental inter- ventions for the safeguard of the island led to the suspension and redesign of operations. This caused delays and additional costs (Giupponi \& Rochier, 2001). Suman et al. (2005) report that local authorities in the Venice area traditionally do not apply a participatory approach.

\section{Findings on Proximity to Protected Areas and on Having Visited the Sites}

The survey reveals that citizens who live closer to the Venice Lagoon value protected areas more in monetary terms than those who live further away in municipalities which are not located along the coast. This result indicates that proximity is a factor determining the level of engagement of stakeholders in environmental protection.

Survey results also reveal that those who have visited the sites and are practically more familiar with them value the two protected areas more than non-visitors. Familiarity with specific sites can be linked to proximity and may even be an overlapping factor.

These findings can be used and interpreted to understand which groups of citizens and stakeholders are more suitable to undertake measures for the safeguard of the two protected areas of the Venice Lagoon.

Halpern et al. (2007) suggest that some threats to biodiversity, such as climate change, are to be addressed from regional to global scale, whereas other threats, such as coastal development, require local to regional interventions.

Smart and Viñals (2004) identify the Venice province as a key actor for the safeguard of the Venice Lagoon and its promotion to a Ramsar site. The same authors describe the efforts made by the province in the late 1990s and early 2000s in implementing a participatory approach through the organisation of a seminar, direct personal contacts, discussion groups, and a public exhibition. Borrelli et al. (2007) explain that provinces often develop effective communication networks with local communities. Analysing how biodiversity conservation is dealt with in the Lazio region, the same authors conclude that it is a local issue which is to be addressed principally by municipalities.

One final aspect which is to be taken into account in the identification of groups of citizens who can play a relevant role in environmental protection and in the implementation of Natura 2000 is familiarity with the concerned sites. By creating a linkage between those who are familiar with a protected area and the importance attributed to cultural heritage as a non-use value (17 per cent of all preferences expressed in the survey), those who have a solid traditional knowledge of concerned areas may represent a relevant stakeholder group for environmental protection. In the case of the Venice Lagoon, the active participation of such a group would result in the implementation of guiding principles for UNESCO World Heritage Sites which urge the inclusion of cultural values of wetlands in the effective management of a site.

\section{Is the Management of the Coastal Zone of the Venice Lagoon Becoming More Sustainable?}

To try to draw some conclusions in this regard, the 2010 situation depicted through the presentation of findings in the preceding chapters can be compared to the present (2012). Since 2010, there have been some changes which make it im- 
possible to conduct another survey based on the same questions. Some relevant facts and observations will therefore be used to compare the past and the present.

To sum up, in 2010 public authorities seemed to favour economic development and employment creation through the expansion of cruise ship tourism over the safeguard of protected areas. The participation of local citizens in decision-making processes was very poor. Local citizens seemed to value their surrounding environment and were ready to pay about 10 euros in an annual tax for the protection of the coastal zone. In particular, they valued the assets they received from the past (cultural heritage), would have liked to preserve it for future generations, and strongly supported biodiversity conservation. In other words, local citizens wanted their surrounding environment to remain unchanged.

In 2012, the project of building a cruise ship harbour was abandoned. This could be the result of the economic crisis which led to a freeze of public investments, but it could also be due to a change in the public administration after elections in 2010 (Boato, 2010).

In 2010 many official public documents explaining future plans of the public administration on the coastal zone were available, whereas in 2012 essentially no relevant official document can be found. This could be again due to the difficult economic situation and the general lack of public financial resources to launch new projects for infrastructure development, or to a more prudent approach towards the environment of the new administration (Ibid). However, some non-official sources, such as newspapers and NGOs, mention several ideas on the development of port facilities in the Venice Lagoon which would have a negative impact on protected areas, and which seem to be under discussion (La Repubblica, 2012; Lanapoppi, 2012).

The terrible accident of the Costa Concordia cruise ship on the coastal area of the Giglio Island (Italy) which occurred in January 2012 initially generated discussions on the concrete danger that cruise ships constitute for the Venice Lagoon. Alternative paths for cruise ships out of Venice were being considered. Nonetheless, only a few months later, the positive economic effects of tourism prevailed again, and nowadays cruise ships keep having direct access to the Lagoon and the city of Venice. A cruise ship accident on 6 May 2012, which by pure chance did not have any major consequence, was barely reported by the press and did not determine any change in the usual way of doing business (Italia Nostra, 2012).

Compared to 2010, in 2012 environmental issues gained relevance in public political discussions. In particular, the recent political campaigns for local administrative elections (May 2012) were characterized by lively debates on the environment (Michele Boato, personal communication, spring 2012).

Table 2 shows the weight that economic, social and environmental aspects had in 2010 and currently have in the management of the coastal area of the Venice Lagoon. A positive change can be observed in terms of citizens' participation in decision-making processes through political events.

\section{Conclusion}

The relevance of the survey presented in this paper lies in the somewhat innovative CVM approach which has been adopted. This methodology allows for the identification of the environmental aspects that citizens value the most, and to design policy
Table 2.

Sustainable development and the management of the coastal zone of the Venice Lagoon.

\begin{tabular}{lll}
\hline & 2010 & 2012 \\
\hline Economic development & high & high \\
Social dimension (citizens’ participation) & low & high \\
Environmental protection & low & low \\
\hline
\end{tabular}

measures reflecting their environmental preferences. The application presented in this paper has a limited relevance due to the low response rate of the survey, but nonetheless, it clearly shows the benefits of the methodology.

An issue which is very important for regional authorities in Veneto, especially after the recent financial crisis, is the creation of employment through the development of economic activities. Additional research is needed on the potential employment generating effects of investments in environmental protection, as opposed to the currently planned investments in infrastructure development and tourism. This concern is common in many coastal areas in the world and should therefore be given more attention to through the allocation of resources for research in this field.

\section{Acknowledgements}

I would like to extend sincere thanks to the manager of Eurosms, Luigi De Gobbi, for allowing me to use the services of his company to conduct the online survey free of charge. Several technicians from different local administrations and NGO representatives were very active in providing useful documents, maps, information, and technical opinions. These include Gustavo De Filippo, expert in environmental planning and environmental impact assessment from the Venice Municipality, three officials from the regional administration who wish to remain anonymous, Piergiorgio Fassini, a sustainable hunter and member of the Council of the Mira Municipality, Giuseppe Cherubini, responsible for the hunting and fishing sector of the Venice Province, Angelo Mancone from the environmental NGO, Legambiente Veneto, and Michele Boato from Ecoistituto Italia. Special thanks are due to Emanuele Stival, Florence Bonnet, Makiko Matsumoto, In-Kon Kim, Blaise Gauchat, and David Gómez for their inputs at different stages of the research work. Last but not least, I shall not forget to thank Michael Warner of the University of London for supervising my research work from September 2009 to August 2010.

\section{REFERENCES}

Allen, J. C., Bergstrom, J., \& Pemberton, C. (2003). Measuring values for wetlands protection in a developing country from domestic and international citizen groups. Prepared for presentation at the American Agricultural Economics Association annual meeting, Montreal, Canada.

http://ageconsearch.umn.edu/

Ambito Territoriale di Caccia Lagunare Venezia (2009). Considerazioni in merito alla Tutela e valorizzazione del territorio lagunare e prelagunare di Mira. Letter to regional authorities, Venezia.

Autorità Portuale di Venezia (2008a). Comunicato Stampa Il Porto di Venezia domani. Press Release, Venezia, 11 September.

http://www.port.venice.it/pdv/archivio/2008/comunicati/apv_com_08 0911_approvato_pot.pdf;jsessionid=3630CD8EDFC677A8C9D8732 17EFA548C 


\section{S. DE GOBBI}

Autorità Portuale di Venezia (2008b). Comunicato Stampa POT 20082011: Piano operativotriennaleoggi in comitatoportuale. Press Release, Venezia, 31 July.

http://www.port.venice.it/pdv/archivio/2008/comunicati/apv_com_08 0731_pot_08-11.pdf;jsessionid=D8DEEA071CEE344F3C4D51BBB 7FDD2AD

Autorità Portuale di Venezia (2008c). Sviluppare l'intermodalità: Il Programma Marco Polo. Primo Piano, Rivista Bimestrale, August, Venezia.

http://www.port.venice.it/pdv/rivista/pdf//2008/Primo_Piano_0808.p df;jsessionid=5A209FADFD4B13C7505D2C83799D81EF

Autorità Portuale di Venezia (2011). Relazioneannuale 2010.

http://85-18-31-142.ip.fastwebnet.it/it/relazione-annuale-2010.htm

Barbier, E. B. (2010). Green stimulus, green recovery and global imbalances. World Economics, 11, 149-177.

Barbier, E. B., Acreman, M., \& Knowler, D. (1997). Economic valuation of wetlands: A guide for policy makers and planners, Gland, Switzerland.

http://www.teebweb.org/Home/tabid/924/language/en-US/Default.as px

Bateman, I. J., Langford, I. H., \& Graham, A. (1995). A survey of nonusers' willingness to pay to prevent saline flooding in the Norfolk Broads. CSERGE Working Paper GEC 95-111. Centre for Social and Economic Research on the Global Environment, School of Environmental Sciences, University of East Anglia, Norwich.

Bird Life International (2009). IBA factsheet Venice Lagoon. (A website).

http://www.birdlife.org/datazone/sites/index.html?action=SitHTMDe tails.asp\&sid=2739\&m=0

Birol, E., Karousakis, K., \& Koundouri, P. (2006). Using economic valuation techniques to inform water resources management: A survey and critical appraisal of available techniques and an application. Science of the Total Environment, 365, 105-122. http://dx.doi.org/10.1016/j.scitotenv.2006.02.032

Blanch, S. (2008). Comment: Towards a Sustainable Northern Australia. Ecological Management and Restoration, 9, 110-115. http://dx.doi.org/10.1016/j.scitotenv.2006.02.032

Boato, M. (2010). Da Galan a Zaia, cosa cambia per l'ambienteveneto? Agorà Magazine. http://www.agoramagazine.it/agora/spip.php?auteur122

Borrelli, G., Carrabba, P., Di Giovanni, B., Padovani, L.M., \& Palma, R. (2007). Politica Locale e Biodiversità. Ente per le NuoveTecnologie, l'Energia e l'Ambiente (ENEA), Roma.

Brander, L. M., Florax, R. G. J. M., \& Vermaat, J. E. (2006). The empirics of wetland valuation: A comprehensive summary and a metaanalysis of the literature. Environmental and Resource Economics, 33, 223-250.

http://dx.doi.org/10.1007/s10640-005-3104-4

Burton, T. M., \& Tiner, R. W. (2009). Ecology of wetlands, in Encyclopedia of Inland Waters, pp. 507-515.

Cheong, Wa D. (2009). Briefing on the Green New Deal for foreign correspondents, a Korean website in English, Seoul, Republic of Korea.

http://english.president.go.kr/main.php

Comune di Mira (2010). Comunicatostampa 16 marzo 2010, Press Release, Mira, Venezia.

Comune di Venezia (2009). Atlante dellaLaguna: Veneziatra Terra e Mare. Venezia.

http://atlante.silvenezia.it/it/index_ie.html

DEFRA (2007). Valuing the benefits of biodiversity, UK. http://www.defra.gov.uk/environment/biodiversity/documents/econ-b ene-biodiversity.pdf

Ecosystems and Human Well-being: Biodiversity Synthesis, Millennium Ecosystem Assessment (2005).

Giupponi, C., \& Brochier, F. (2001). Integrated coastal zone management in the Venice area: A methodological framework. Nota di lavoro, FondazioneENI Enrico Mattei, Venice. http://papers.ssrn.com/sol3/papers.cfm?abstract_id=293792

Halpern, B. S., Selkoe, K. A., Micheli, F., \& Kappel, C. V. (2007). Evaluating and ranking the vulnerability of global marine ecosystems to anthropogenic threats. Conservation Biology, 21, 1301-1315. http://dx.doi.org/10.1111/j.1523-1739.2007.00752.x

Hanley, N., \& Craig, S. (1991). Wilderness development decisions and the Krutilla-Fisher model: The case of Scotland's flow country. Ecological Economics, 4, 145-164. http://dx.doi.org/10.1016/0921-8009(91)90026-B

Howell, R., \& Kent, R. (2008). R106 research methods. London: School of Oriental and African Studies.

Italia Nostra (2010). Il moto ondoso a Venezia e nella sua laguna. Sezione di Venezia, Venezia.

http://www.italianostra-venezia.org/3campagn/SoloMO/MOndosoO KOK.htm

Italia Nostra (2012). Incidentetaciuto e nascosto a nave da crocieranellastazionemarittima del porto di Venezia.

http:/groups.google.com/group/nograndinavivenezia/browse_thread/ thread/7c3156c855e2bf57/167327f1c4d39dff?show_docid=167327f1 c4d39dff

King, D. M., \& Mazzotta, M. J. (2000). Contingent Valuation’ in Ecosystem Valuation.

http://www.ecosystemvaluation.org/contingent_valuation.htm

Korea.net News (2009a). Four-river restoration plan stepped up. http://www.korea.net/

Korea.net News (2009b). Government starts "four major rivers restoration project”. http://www.korea.net/

Lanapoppi, P. (2012). E adesso le grandinavi. Italia Nostra Venezia. http://www.italianostra-venezia.org/index.php?option=com_blog\&vi ew=blogger\&bn=Paolo+Lanapoppi\&Itemid=0\&lang=it

La Repubblica (2012). Venezia: Il nuovocorridoio Uesblocca il porto. 16 gennaio 2012, p. 22, Senzione: Affari Finanza.

http://ricerca.repubblica.it/repubblica/archivio/repubblica/2012/01/16 /venezia-il-nuovo-corridoio-ue-sblocca-il.html

Pagiola, S., von Ritter, K., \& Bishop, J. (2004). Assessing the economic value of ecosystem conservation. Washington D.C.: The World Bank Environment Department, Environment Department Paper No. 101. http://www.teebweb.org/Home/tabid/924/language/en-US/Default.as $\mathrm{px}$

Ramsar Convention (2010). List of Ramsar sites. http://www.ramsar.org/cda/en/ramsar-home/main/ramsar/1\%5e7715 _4000_1_

Ramsar Convention (2004). The Ramsar Convention. http://www.ramsar.org/cda/en/ramsar-news-archives-2004-ramsar-m eets-venice-for/main/ramsar/1-26-45-54\%5E18303_4000_0

Regione del Veneto (2008d). Rapporto ambientale del piano territoriale regionale di coordinamento, Venezia.

http://www.k-servizi.com/download/ptrc/dgr372/Rapporto_ambienta le_PTRC_adozione.pdf

Regione del Veneto (2009a). Deliberazionedella giunta n. 372 del 17 febbraio 2009: Adozione del piano territoriale regionale di coordinamento, Venezia. www.regione.veneto.it

Regione del Veneto (2009b). Documento di valutazione di incidenza del piano territoriale regionale di coordinamento, Venezia. www.regione.veneto.it

Regione del Veneto (2009c). Natura 2000 data form codicesitoit 3250046 laguna superiore, Venezia. www.regione.veneto.it

Regione del Veneto (2009d). Retiecologiche e biodiversitànel Veneto, Venezia. www.regione.veneto.it

Regione del Veneto (2009e). Hub principalidellalogisticaveneta: Il progettostrategicodellaportaorientale, documentopreliminare, Venezia.

http://bur.regione.veneto.it/BurvServices/pubblica/DettaglioDgr.aspx ?id=221600

Regione del Veneto (2009f). IndividuazionedelleZPS per le quali è necessario un piano di gestione, Venezia. http://www.regione.veneto.it/Ambiente+e+Territorio/Territorio/Reti +Ecologiche+e+Biodiversità/Piani+di+Gestione+ZPS.htm

Regione del Veneto (2009g). Misure di conservazione, Venezia. http://www.regione.veneto.it

Regione del Veneto (2009h). L’applicazionenel veneto, Venezia. http://www.regione.veneto.it

Regione del Veneto (2011). Rapportostatistico 2011.

http://statistica.regione.veneto.it

Sands, P. (2003). Principles of international environmental law (2nd 


\section{S. DE GOBBI}

ed.). Cambridge: Cambridge University Press.

http://dx.doi.org/10.1017/CBO9780511813511

Smart, M., \& Vinals, M. J. (2004). The lagoon of Venice as a ramsar site, commissioned by the province of Venice.

http://www.ramsar.org/cda/en/ramsar-news-archives-2004-lagoon-of -venice-as-22458/main/ramsar/1-26-45-54^22458_4000_0_

Solidoro, C., Bandelj, V., AubryBernardi, F., Camatti, E., Ciavatta, S., Cossarini, G., et al. (2010). Response of the Venice lagoon ecosystem to natural and anthropogenic pressures over the last 50 years. In M. J. Kennish, \& H. W. Paerl, (Eds.), Coastal lagoons: Critical habi- tats of environmental change (pp. 483-511). Boca Raton, FL: CRC Press.

Suman, D., Guerzoni, S., \& Molinaroli, E. (2005). Integrated coastal management in the Venice lagoon and its watershed. Hydrobiologia, 550, 251-269. http://dx.doi.org/10.1007/s10750-005-4393-x

Turner, R. K., van den Bergh, J.C.J.M., Söderqvist, T., Barendregt, A., van der Straaten, J., Maltby, E., \& van Ierland, E.C. (2000). Ecological-economic analysis of wetlands: Scientific integration for management and policy. Ecological Economics, 35, 7-23.

http://dx.doi.org/10.1016/S0921-8009(00)00164-6 